\title{
FEDERAL INCOME TAXATION: BAD DEBT RESER VES HELD TAXABLE TO TRANSFEROR IN A SECTION 351 TRANSFER
}

In Nash v. United States ${ }^{1}$ the Court of Appeals for the Fifth Circuit determined that a bad debt reserve is taxable to the members of a partnership upon the transfer of accounts receivable to a controlled corporation under section 351 of the Internal Revenue Code. ${ }^{2}$ Prior to June I, 1960, the petitioners were accrual basis taxpayers who operated several finance businesses as a partnership which used the reserve method of accounting for bad debts. ${ }^{3}$ Subsequently, the partners incorporated some of the businesses by transferring, pursuant to section 351 , accounts receivable and bad debt reserves to new corporations which carried the bad debt reserves as a deduction from accounts receivable in an effort to show the net value of the receivables. ${ }^{4}$ The Commissioner agreed that the reserves were reasonable in amount ${ }^{5}$ but contended that the partnership should have included the reserves in taxable income for its final fiscal year. ${ }^{6}$ In finding for the Commissioner, the Fifth Circuit reversed the district court and placed itself in direct conflict with the Ninth Circuit. $^{7}$

Section 35 I permits property to be transferred to a corporation without recognition of gain or loss if the transferor controls the corporation immediately after the transaction and the exchange was solely for stock or securities of the corporation. ${ }^{8}$ This legislation was enacted with the objective of easing the transition from proprietorship to corporation by removing the previous presumption in favor of a taxable exchange.9 The premise of section $35 \mathrm{I}$ is that

\footnotetext{
1414 F.2d 627 (5th Cir. 1969), cert. granted, 38 U.S.L.W. 3248 (U.S. Jan. 12, 1970) (No. 678).

'INT. REV. CODE of 1954, \$351.

3414 F.2d at 629.

IId.

'Birmingham Trust Nat'l Bank v. United States, 68-2 U.S. Tax Cas. 87,779, 87,781 (N.D. Ala. 1968).

414 F.2d at 629.

IId. at 630, see Estate of Schmidt v. Commissioner, 355 F.2d 111 (9th Cir. 1968).

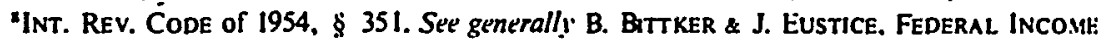
Taxation of Corporations and Shareholders $\$ 3.01$ (2d ed. 1966) thereinafter cited as ButTKER \& ËUSTICEl.

'S. Rep. No. 275, 67th Cong., Ist Sess. 11 (1921). "The existing law makes a presumption in favor of taxation. The proposed Act [the predecessor of $\$ 351$ ] modifies that presumption
} 
a transfer which is solely for the purpose of changing the form of a business should not require recognition for tax purposes. ${ }^{10}$ There is no legislative history or statutory definition of section 351 "property," but services are explicitly excluded." The property involved in Nash was a reserve for bad debts which is provided for. in section $166(\mathrm{c})^{13}$ and established in expectation of future losses on outstanding receivables. ${ }^{14}$ When the need for this reserve ceases as it does through collection of the face value of the receivables, the unused reserve must be returned to income. ${ }^{15}$ In Revenue Ruling 62128 the Internal Revenue Service indicated that a bad debt reserve would not be transferrable under section 351 because the transferor's nced for the reserve had ceased..$^{16}$ However, the cases cited therein did not support this ruling, ${ }^{17}$ since both involved liquidations where the business ceased to operate in any for $\mathrm{m}^{18}$ rather than section 351 transactions where operations continue through a different legal organization.

Other sections of the Internal Revenue Code provide illustrations of the transferrability of various reserves without recognition of income to the transferor in a section 351 transaction. ${ }^{19}$ The treatment of these reserves provides a useful analogy since they have the potential for later becoming income to the transferee just as the bad debt reserve would have been income to the corporation if the receivables were collected without the anticipated losses. For

by providing that ... no gain or loss shall be recognized unless the property received in exchange has a readily realizable market value . . . Id. See also H.R. REP. No. 1337, 83d Cong., 2d Sess. Al 16 (1954) (no change in basic purpose of section).

"BTtKK:R \& l:USTICE $\$ 3.01$ at 66 .

"Id. \$3.02 at 69.

"1NT. Rtv. Cod: of 1954, $\$ 351$ (a). See also H.R. Rep. No. 1337, 83d Cong., 2d Sess. All7 (1954).

"INT. REV. CODE of 1954, \$166(c).

"Ira Handleman, 36 T.C. 560,565 (1961).

${ }^{15}$ C. Standlee Martin, Inc. v. Riddell, 56-2 U.S. Tax Cas. 56,578 (S.D. Cal. 1956); Bird Management, Inc., 48 T.C. 586 (1967); Cardinal Finance Co., 32 P-H Tax Ct. Mem. 103 (1963); Ira Handleman, 36 T.C. 560 (1961).

"Rev. Rul. 128, 1962-2 CUM. BuLl. 139.

"66 CoLUM. L. Rev. 1187 (1966).

ixC. Standlee Martin. Inc. v. Riddell, 56-2 U.S. Tax Cas. 56,578 (S.D. Cal. 1956); Geyer, Cornell \& Newell, Inc., 6 T.C. 96 (1946); 53 MinN. L. Rfv. 1354, 1355 (1969).

"The fact that the transferrability of other reserves is specifically allowed by the Code may suggest that congressional silence on the transferrability of bad debt reserves should be interpreted as an intent that bad debt reserves be taxed in a section $35 \mathrm{I}$ transaction. However. this silence would appear to be neutral since there are no statutory provisions regarding the transferrability of bad debt reserves under any circumstances. See note 74 infra. 
example, in a section 351 transfer, there is no requirement that depreciation on personal property be recaptured under section $1245,{ }^{20}$ and section 1250 likewise exempts the recapture of "excess" or greater than straight line depreciation on realty. ${ }^{21}$ Although section $111^{22}$ requires that gross income be increased to the extent of a prior exclusion when a bad debt is collected and thereby indicates a Congressional policy to apply the tax benefit rule to accounts receivable rather than to treat the reserve as reducing basis as is done with depreciated property, this rule would not seem to operate in a section $351^{23}$ transfer since there has been no "recovery" of the bad debt. ${ }^{24}$ Section 47(b) does not require recapture of an in vestment credit "by reason of a mere change in the form of conducting the trade or business ...."25 and an example in the Regulations places a 351 transaction within this exclusion. ${ }^{26}$ Notes representing installment sales on which the gain is to be postponed under section $453^{27}$ may be transferred without recognition of the unrealized profit although there is no specific statutory approval for this treatment. ${ }^{28}$ Further, at least one commentator states that a reserve for the replenishment of LIFO inventory is transferrable. ${ }^{29}$

In addition to these sections, which deal with analogous reserves,

\footnotetext{
INT. REV. CODE of 1954, § 1245(b)(3). See generally Blanc, The Tax Treatment of Reserves L'pon a Change' in the Form of Doing Business. U. So. CaL. 1967 TAX. INST. 433. 442.

${ }^{21}$ INT. REV. CODE of 1954. $\$ 1250$ (d)(3).

2Id. $\$ 111$.

चId. \$35I.

${ }^{21} / d$. $\$ 111$ (a). See note $66 \mathrm{inf} / \mathrm{ra}$ and accompanying text. In the normal case of a taxpayer correcting a prior mistake in the amount of the bad debt reserve. the tax benefit rule does not apply and the mistake is reflected in a lesser amount being transferred to the reserve for the coming tax year. Treas. Reg. $\$ 1.166-4$ (1959).

${ }^{25}$ INT. Riv. CoDi: of 1954, \$ 47(b)(2).

"Treas. Reg. \$ 1.47-3(f)(6) example (1) (1967); Benjamin, Problems in Transilion From Solo Propriclorship or Parmership io Corporation, N.Y.U. 26TH INST. ON FHED. TAX. 791. 793-94 (1968).

${ }^{2}$ INT. Riv. CODE of 1954, \$453.

20Treas. Reg. $\$ 1.453-9$ (c)(2) (1958); se', c.g.. Sohmer \& Co. v. United States, 86 F. Supp. 670 (S.D.N.Y. 1949). Some cases have gone further by allowing cash basis taxpayers to transfer assets under section 351 without requiring them to transfer the matching expenses of creating the asset. Commissioner v. South Lake Farms, Inc., 324 F.2d 837 (9th Cir. 1963) (growing crops); Divine v. United States, 62-2 U.S. Tax Cas. 85,589 (W.D. Tenn. 1962) (inventory): Thomas W. Briggs, 25 P.H Tax Ct. Mem. 56-349 (1956) (accounts receivable). But cf. Rooney v. United States, 305 F.2d 681 (9th Cir. 1962) (growing crops).

"Stoffel. Trearment ol Reserve Iccounts on Incorporation and Liquidation. N.Y.U. 26TH INST. ON Fi:D. TAX. 773, 784 (1968).
} 
the doctrine of anticipatory assignment of income ${ }^{30}$ can be beneficially considered, since it would permit the tax free transfer of bad debt reserves, while requiring the transferor to pay tax on any reserves subsequently returned to income by the transferee. In $H$. B. Zachry Co., ${ }^{31}$ the Tax Court allowed the tax free transfer of "carved-out"32 oil payments under section 351, but stated that the question of whether or not the subsequent income would be taxable back to the transferor was not before the court. ${ }^{33}$ This suggests that a section 351 transfer may be permitted even though assignment of income principles could be applied to require the transferor to pay taxes on subsequent income. ${ }^{34}$

In Estate of Heinz Schmidt, ${ }^{35}$ the first case after Revenue Ruling 62-128 36 and a case identical to Nash, the Tax Court held that a partnership's bad debt reserve would not qualify as a tax free transfer under section 351 (a) but would constitute taxable income since the partnership no longer had a "need" for the reserve. The purported authority for this holding was a case in which the taxpayer disposed of all of its assets in a tax free transaction pursuant to a plan of complete liquidation under section $337^{37}$ but was required to pay tax on the bad debt reserve which was no longer needed. ${ }^{38}$ The Tax Court in Estate of Schmidt indicated that a contrary result would be desirable but refused to so hold since the Internal Revenue Code, while allowing the carryover of basis of transferred assets, ${ }^{39}$ does not specifically allow the transfer of bad debt reserves. ${ }^{40}$ The Court of Appeals for the Ninth Circuit reversed," placing emphasis not only on the fact that this was the

\footnotetext{
${ }^{50}$ For a comprehensive discussion of assignment of income see Biblin. . Issignme'mt of Income in Conne'tion with Incorporating and Liquidating Corporations, U. So. CAL. 1969 TAX INST. 383.

34 49 T.C. 73 (1967), appeal dismissed per stipulation, 3 P-H 1969 FED. TAXES I 18,023.

s:"Carved-out" oil payments represent rights to oil and gas in place that extend over a period of time less than the life of the property. 4 P-H 1969 FED. TAXES If 32,561.

349 T.C. at 80 n.5.

"Biblin, supra note 30 , at 387 . This contention is bolstered by the fact that there will be an anticipatory assignment of income only in those cases where the bad debt reserve is later returned to income by the transferet.

$=42$ T.C. 1130 (1964), revid. 355 F.2d 111 (9th Cir. 1966).

"See note 16 stupra and accompanying text.

"INT. Ri:v. COnE of 1954, \$337(a).

¿x West Seattle Nat'l Bank v. Commissioner, 288 F.2d 47 (9th Cir. 1961).

32 T.C. at 1136.

$+/ d$.

"Estate of Schmidt v. Commissioner. 355 F.2d 111 (9th Cir. 1966).
} 
first attempt since the enactment of the section in 1921 to so limit these transfers ${ }^{42}$ but also on an economic analysis illustrating that the corporate stock received by the transferor represented the net value of the receivables, not the gross value..$^{33}$ Although two district courts have followed the Ninth Circuit in holding for the taxpayer, the Tax Court in Max Schusterts maintained its original position, with three judges dissenting. ${ }^{16}$ Again, the primary basis for Schuster was the lack of specific statutory authorization for the transfer of bad debt reserves. ${ }^{17}$

In Vash, the Fifth Circuit accepted the Commissioner's position ${ }^{48}$ on the basis of its interpretation of the postponement objective of section $351^{49}$ and the fact that a contrary result would change the identity of the taxpayer. ${ }^{50}$ Adoption of the Commissioner's position was an acceptance of the Tax Court's rationale that the taxpayer no longer "needed" the reserve and that the absence of bad debt reserves from the language of section 351 prevents a tax free transfer.51 Admitting to its lack of preciseness regarding the justification of section 351 tax free exchanges, the court stated that the general purpose of section 351 is merely to

\footnotetext{
Eld. at 112 .

"Id. at 113 .

"Scofield v. United States, 23 Am. leed. Tax R.2d 69-1447 (C.D. Cal. 1969): Rowe v. United States. 23 Am. Fed. Tax R.2d 69-443 (W.D. Ky. 1968), upneal authorizud, P-H 1969 Fin. TAX:s Citator 12.107.

"50 T.C. 98 (1968). appeal fitcel. P-H 1969 Fit. TAXt:s Citator 10.192: alccord. Robert P. Hutton. P-H TAx Cr. Rt:P. \& Mt:M. Dic 53.6 (Oct. 13. 1969). Hutton and Schustior. unlike Nash, involved cash basis taxpayers. The Tax Court distinguished Hullon from the Ninth Circuit's determination in Schmidt that the Commissioner's taxing of the transferor would create "fictitious income, never realized by the taxpayer in fact," 355 F.2d at 114 , by indicating that a cash basis taxpayer, like Hutton, reports income in the year received, and therefore there is 10 possibility that a presently reported item of income will become uncollectible in the future. 53.6 at 28-53. Perhaps the Commissioner is more justified in resisting this type of "tax benefit" when the income representing the accounts receivable for which the bad debt reserve has been created has not been reported under the cash basis accounting method. The more reprehensible event occurred not at the time of the section 351 transaction. but when the taxpayer was allowed to deduct additions to the bad debt reserve although no income for the accounts receivable had been recognized. A possible remedy, other than the one adopted in this specific instance. would be to require the recognition of the income by the transferor under assignment of income principles.

"50 T.C. at 103.

"Id. at 102.

$\times 414$ F.2d at 629.

"Id. at 630 .

sold.

st See notes 36-40 supra and accompanying text.
} 
postpone a gain or loss until the gain or loss is actually realized by the transferor.$^{52}$ It was argued that the allowance of a contrary result would amount to recognition of a loss due to the failure of the transferor to collect the receivables and that this would be contrary to the purpose of the statute. ${ }^{53}$ The court concluded that if any part of the reserve were not needed by the corporation, the tax on the portion returned to income would not only have been postponed, but also the identity of the ultimate taxpayer would have been changed, which would result in taxing any portion of the reserve not used by the transferee at corporate rather than individual rates.5

The validity of the Fifth Circuit's conclusion in .Vash is questionable because it relies on Tax Court opinions based on questionable precedents and incorrectly applies the congressional intent manifested in section 351. The cases and Revenue Ruling ${ }^{55}$ underlying the Tax Court's position ${ }^{56}$ provide poor authority since they involve complete terminations of business operations rather than section 351 transactions where there is merely a change in legal form. ${ }^{53}$ The Tax Court's contention that the transfer cannot be allowed on strict statutory grounds ${ }^{58}$ is based on the indisputable fact that the statute does not mention bad debt reserves and contains no definition of property. According to rules of statutory construction,

$\$ 214$ F.2d at 630 .

ss/d. The court's determination that a loss will result at the time of the transfer of the accounts receivable to the corporation appears to be premised upon the view that the partnership's basis in the accounts receivable was their face amount, 414 F.2d at 630, and that the corporation bought the receivables for their net amount. id., thereby creating a loss to the partnership in the amount of the bad debt reserves. The assignment of this basis to the partnership, however. requires bringing the bad debt reserves back into income and thus negates the previous determination by the partnership that some accounts receivable would prove uncollectible, for which it had set up the reserve. Thus treatment by the court is necessarily premised upon the view that the reserve was merely an accounting device by which the partnership for income tax purposes deducted the expense before a loss actually took place - when the accounts proved uncollectible or when the accounts were sold for less than their face value. For a discussion of the fallacy of this view see notes $62-64$ and $77-81 \mathrm{~m} / \mathrm{ra}$ and accompanying text.

st414 F.2d at 630 .

ssee notes 16-18 supra and accompanying test.

"See notes 35 \& 37-38 supra and accompanying text.

${ }^{57}$ See Estate of Schmidt v. Commissioner, 355 F.2d 111, 113 n.7 (9th (ir. 1966): Hickman. Incorporation and Capitalization: The Threal of the "Potential Income" It'tn and a Sinsible Approach to Problems of Thinness. 40 TAxES 974, 977-78 (1962): 12 N.Y.L.F. 145, 149 (1966): notes 16-18 supra and accompanying text.

sxF.g., Max Schuster, 50 T.C. 98, 102 (1968), appcal filed. P.H 1969 Ht.1). TAxi:s (itAtor 10,192 . 
however, the single exception of services in section $351(a)^{59}$ suggests that all other items are to be considered property for section 351 purposes and are therefore transferrable..$^{60}$ Moreover, as the dissent in Max Schuster indicates, the carryover from one legal form to another of tax attributes such as undistributed profits and unamortized bond discount has been allowed without specific statutory authorization. ${ }^{11}$ The court's reasoning that a contrary result would actually conflict with the purpose of section $351^{62}$ can be disputed on two grounds. First, assuming that the district court was correct in its finding that the reserve was reasonable, ${ }^{23}$ the loss due to the predicted failure to collect a portion of the receivables occurred when the reserve was established and not at the time of the transfer. ${ }^{64}$ Second, assuming arguendo that the reserves are not needed, they must ultimately be returned to income albeit by the transferee. ${ }^{65}$ Therefore, there has been no tax avoidance ${ }^{66}$ but rather, at most, a change in tax rate. This result actually furthers the postponement objective by delaying the incidence of the tax until the gain is realized by disposition of the receivables. Further, the result in Vash is in conflict with congressional intent as expressed by the legislative histor $y^{67}$ of section 351 , since the consequence of . Nash will be to increase rather than remove impediments to changes in legal form. ${ }^{68}$

Adoption of the court's position would create inconsistencies in the application of section 351 to the transfers of analogous potential income items and would distort the income of both the transferee and transferor. Reserves for depreciation can be transferred without

\footnotetext{
3INT. RFv. CODE of 1954. $\$ 351$ (a) states, "for purposes of this section, stock or securities issued for services shall not be considered as issued in return for property."

" "Such a singular and extraordinary exception denotes the scope of the term property under the rule of statutory construction expressio mius est ex/usio altcrius." H.B. Zachry Co., 49 T.C 73.80 n.6 (1967).

" 50 T.C. at 103 n.l (Simpson, J., dissenting).

-See note 53 supra and accompanying text.

- Birmingham Trust Nat'l Bank v. United States, 68-2 U.S. Tax Cas. 87,779, 87,781 (N.D. Ala. 1968).

"53 MinN. L. Rriv. 1354, 1358 (1969).

SSee note 15 supra and accompanying text.

- Pennell. Curre'nt Problemts in Parmerships. U. So. Cal. 1968 Tax INst. 315. 358.

- See notes 9 \& 10 supra and accompanying text.

¿xMax Schuster. 50 T.C. 98, 103-04 (1968) (Dawson \& Simpson, JJ.. dissenting), appeal filed. P-H 1969 Fit. TAXEs Citator 10,192; Blanc, supra note 20 at 464, 474; se' BitTk:R \& Fustice $\$ 3.01$ at 66 .
} 
requiring the transferor to include them as income, ${ }^{69}$ yet these reserves, like the reserve for bad debts, have the potential for becoming future income to the transferee. ${ }^{70}$ Further, investment credit, which has similar attributes to the bad debt reserve in that it must be "recaptured" if the asset which created the credit is disposed of, ${ }^{71}$ is not taxed in a section 351 transaction. ${ }^{72}$ These are examples of items which merely have the potential for becoming income in the future. In other instances, section 351 transfers involving installment obligations have been permitted tax free ${ }^{73}$. although not only are these items certain to become income in the future but there has also been a subsequent change in taxpayer identity. It is inconsistent to allow transfers of items which will definitely become income in the future yet disallow the transfer of an item which has only a remote potential for becoming income. The fact that Congress has not prescribed detailed rules regarding the transfer of bad debt reserves ${ }^{74}$ should not be permitted to thwart the apparent policy of section $351,{ }^{75}$ especially since other transfers of potential income items are permitted without specific statutory authorization. ${ }^{76}$ Indeed, an economic distortion will be created when a section 351 transaction is made under the Nash holding. "need" for the bad debt reserve from an economic viewpoint transcends changes in legal form since the transferee has received an asset whose true valuation is less than face value. ${ }^{78}$ The Internal Revenue Service evidently considers that the reserve represents untaxed income $\mathrm{m}^{79}$ while in fact it is the implementation of an accepted accounting principle which recognizes the diminution in the

\footnotetext{
-INT. Rtv. ConE of 1954. \$\$\$ 1245(b)(3), 1250(d)(3). S't' genterally Blanc, supra note 20. at 442-48.

"INT. Rev. ConE of 1954, \$̧\$ 1245(a). 1250(a).

"Id. $\$ 47(\mathrm{a})$.

${ }^{72} I d$. $\$ 47(b)(2)$. See note 26 supra and accompanying text.

${ }^{2}$ See note 28 supra and accompanying text.

"Blanc. supra note 20, at 448. "The treatment of bad-debt reserves upon formal business changes is entirely a product of case law. rulings. and Regulations. Unlike depreciation reserves. Congress prescribed no detailed rules for bad-debt reserves when such transactions occur." Id.

7533 MinN. L. REv. 1354, 1359 (1969).

"Max Schuster. 50 T.C. 98. 104 (1968) (Simpson. J., dissenting), appeal liled. P-H 1969 FED. TAXES Citritor 10,192. See note 28 supra and accompanying text.

"See note 43 supra and accompanying text.

${ }^{7 x}$ See Hickman. supra note 57. at 998: Note. "Mid-Stream" Incorporations, 38 U. CIN. L. REV. 96,110 (1969).

IStoffel, supra note 29, at 773.
} 
value of receivables. ${ }^{80}$ According to Nash, the transferor would be required to include the reserve in income and the transferee would necessarily be permitted to deduct a like amount from its income to set up a new reserve. This would actually distort the income of the two entities ${ }^{81}$ and would therefore be contrary to the principle that the method of accounting should clearly reflect income. ${ }^{82}$ Thus, the holding in Nash appears to be questionable since it is based upon dubious precedents, ignores economic reality, lacks support in legislative history, and creates inconsistencies with analogous transactions under section 351 .

Rejection of Nash would not leave the Internal Revenue Service helpless to deal with section 351 abuses since several feasible alternatives to Nash exist that would allow the fulfillment of congressional objectives without permitting tax evasion. A procedure for examining the reasonableness of bad debt reserves has been established ${ }^{83}$ and could be applied strictly during a section 351 transaction. The Commissioner can require that reserves in excess of a reasonable a mount be restored to income ${ }^{8 t}$ to lessen the probability that the reserves would later become income to the transferee. Utilizing the authority of section $446,{ }^{85}$ the Commissioner can require that the successor continue to utilize the reserve method of accounting for bad debts rather than an individual charge-off of each receivable which becomes uncollectible. This procedure assures that the transferee could not later charge-off a mounts which had previously been allowed for in the reserves of the transferor. ${ }^{86}$ if necessary, the Service may require that excessive reserves be returned to the transferor's income by several approaches. As has been suggested, section 351 does not exclude the ultilization of the anticipatory assignment of income doctrine. ${ }^{87}$ Thus the Service can

\footnotetext{
Blanc, supra note 20, at 444; 66 CoLUM. L. Rev. 1187, $1188-89$ (1966); 53 MinN. L. Rev. 1354, $1357-58$ (1969).

"Arent, Reallocation of Income and Expense Items in Connection with Formation and Liquidation of Corporations, 40 TAXES 995, 998 (1962); 66 ColuM. L. REv. 1187 (1966).

${ }^{27}$ See 1 INT. Rev. Code of 1954, $\S 446(b), 482 ; c /$. Jud Plumbing \& Heating. Inc. v. Commissioner, 153 F.2d 681, 685 (5th Cir. 1946).

Treas. Reg. \$ $1.166-4$ (1959).

w/d.: Blanc, supra note 20, at 471 n.101.

sINT. REV. CODE of 1954, § 446(b).

"See generall! Arent, supra note 81, at 999-1000; Biblin, supra note 30, at 394-95: Pennell, supra note 66, at 358.

${ }^{27}$ Biblin, supro note 30, at 387.
} 
exercise its authority under section $482^{88}$ to allocate income between the transferor and transferee if this is necessary to clearly reflect the income of each ${ }^{89}$ An example of a possible procedure for handhing excess reserves is provided by the Regulation requiring that the in vestment credit for assets subsequently disposed of by the transferee be "recaptured" by the transferor. ${ }^{90}$ Furthermore, in appropriate cases of extreme abuse, the transferee corporation can" be ignored for tax purposes and the entire transaction treated as a sham." In conclusion, the Commissioner should use the above. procedures against possible abuse rather than read section 351 narrowly and thereby thwart the section's purpose of encouraging incorporations.

\footnotetext{
"INT. REV. CODE of 1954, \$482.

- Biblin, supra note 30, at 396; Hickman, supra note 57, at 980.

*Treas. Reg. \$ 1.47-3(f)(5), (6), example 2 (1967).

"Biblin, supra note 30, at 394; Blanc, supra note 20, at 474 n. 108.
} 